\title{
SIGNS ALONG THE TRAIL
}

THE MUSEUM AND NATURE TRAILS AT BEAR MT., N. Y.

\author{
WILLIAM H. CARR \\ ASSISTANT CURATOR, DEPARTMENT OF EDUCATION
}

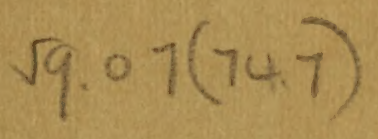

$c_{y}$

\author{
Department of Education \\ THE AMERICAN MUSEUM OF NATURAL HISTORY \\ 77th Street and Central Park West \\ New York City
}

NEW SCHOOL SERVICE SERIES NUMBER TWO

2nd Edition 



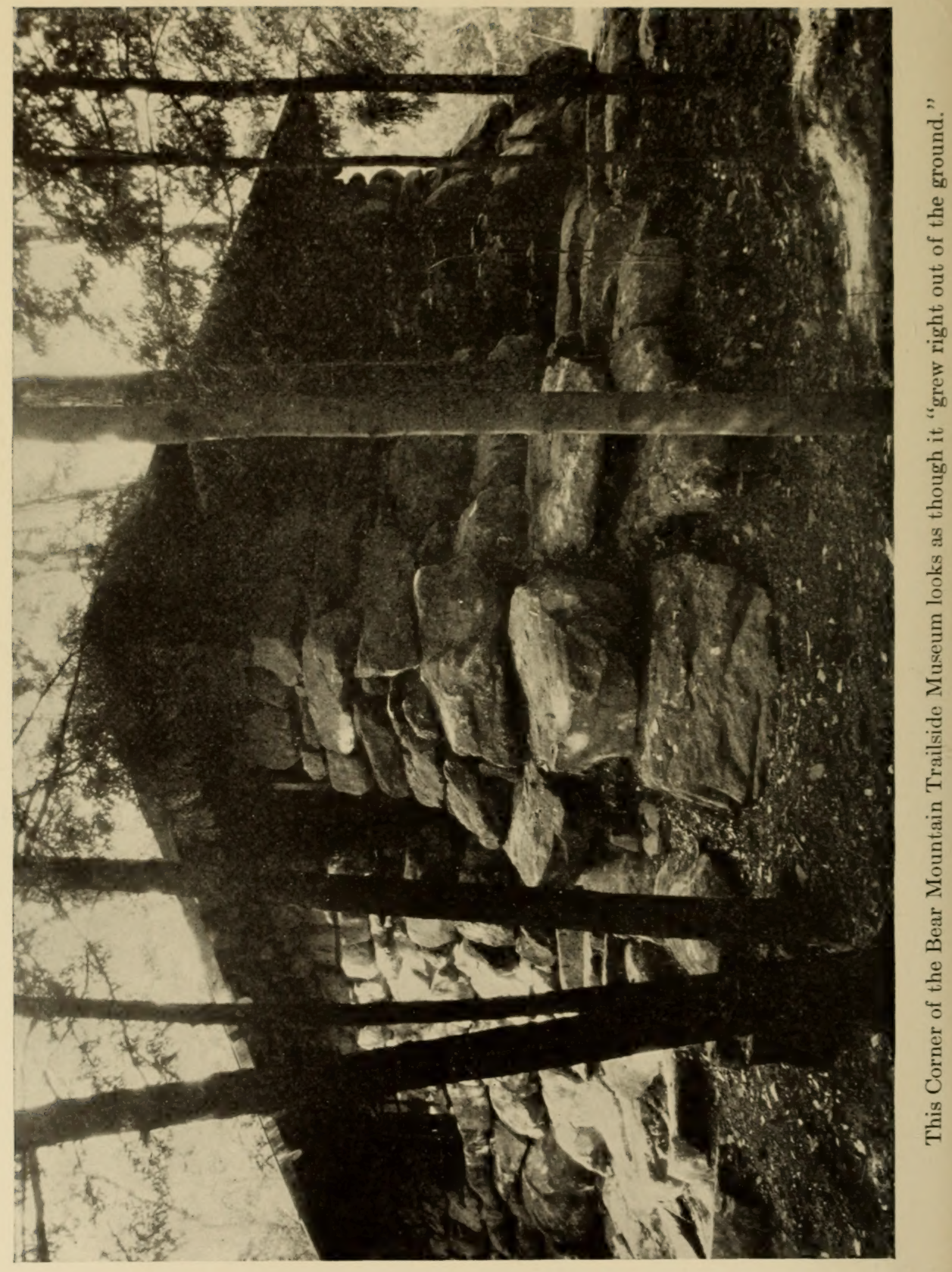




\title{
Signs Along the Trail
}

\author{
WILLIAM H. CARR
}

ASSISTANT CURATOR, DEPARTMENT OF PUBLIC EDUCATION

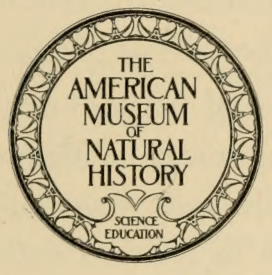

PHOTOGRAPHS By LeROY DAVIES

NEW SCHOOL SERVICE SERIES NUMBER TWO

NEW YORK

1930 
In the Palisade Interstate Park, near its Bear Mountain Headquarters, there is now a Trailside Museum from which radiate about one mile and a half of Nature Trails. The building was constructed by the American Association of Museums with funds provided by the Laura Spelman Rockefeller Memorial. The Commissioners of the Palisades Interstate Park set aside twenty acres of wild woodland admirably fitted for the project and have contributed generously toward both construction and equipment. Major William A. Welch, Park Director, has not only supervised the actual construction of the building but has also shown a great interest in the various phases of the work.

The American Museum of Natural History was invited to undertake the development of the project. William H. Carr, Assistant Curator of the Department of Education, was appointed to build the trails, arrange for exhibits and act as resident naturalist in charge of this important out-door-educational experiment. Mr. Carr was ably assisted by his wife, Marion B. Carr.

During the season some 23,000 persons visited the trails. The museum building was completed in September of 1927 and will be open during the Spring and Summer months of 1928.

George H. Sherwood, Curator-in-Chief, Department of Public Education, American Museum of Natural History, 77th Street and Central Park West, New York City. 


\title{
SIGNS ALONG THE TRAIL
}

\author{
WILLIAM H. CARR
}

An excellent story is often improved by good illustrations. These help to portray the scenes of action and aid in giving a graphic picture of Introduction some of the principal characters. A motion picture story resolves itself into a series of illustrations explained by written captions. In the world out-of-doors Nature has many stories to tell. She has ample illustrations for each one. Most of those stories, however, are lost to the public in the open unless there be some means devised to call attention to various interesting things. In other words, the story that has been previously illustrated must be written. The cart is before the horse. Mere labels upon plants, rocks and other things along the walks and paths are not enough in themselves. In order to appeal to the growing army of people who seek the open air during the four seasons of the year, Nature Trails and Field Museums have been developed in many sections of the country.

At Bear Mountain on the Hudson, in the Harriman section of the Palisades Interstate Park, where tens of thousands of people spend their week-ends and holidays throughout the spring and summer months, we established more than one mile and a half of Nature Trails.

Nature Education in the Park area was inaugurated eight years ago by Mr. B. T. B. Hyde who established the first museum in the Park at the Boy Scout Camps. In five years' time there were smaller museums maintained in many other camps throughout the park. Three years ago in 1925, Dr. Frank E. Lutz, Curator of Insect Life at the American Museum of Natural History, crystallized the Nature Trail idea in connection with his Station for the Study of Insects near Tuxedo, New York. His success was great. Nature Trails spread not only throughout the park but through the country and abroad as well.

Our work commenced in May, 1927. The first problem that confronted us was the actual making of walks and trails. The area given for the project had never previously been utilized. Thus, conditions were ideal for the purpose of planning a series of paths that would be fresh and untrodden. Rocky, fern-filled glades, hilltops, swamp and brooklands, combined with open fields and heavily wooded areas, presented every opportunity to create what would, in effect, be an ideal out-door nature garden, as far as the land itself was concerned.

To take twenty acres of rough, wooded ground and provide it with 

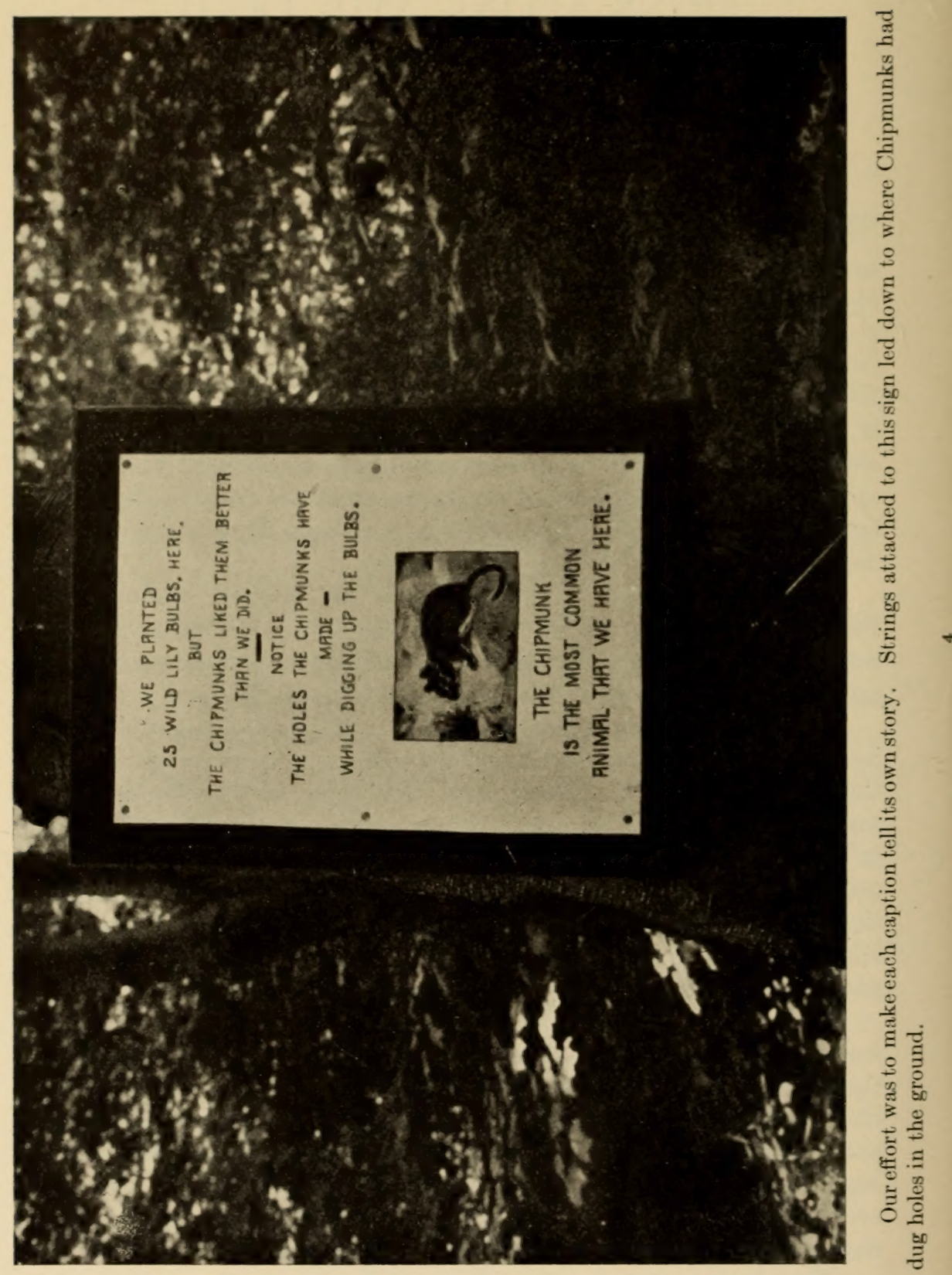
radiating trails is one thing. To equip these trails with labels is quite another proposition. In making the trails we had two objectives in view: one to make them simple to follow, and the other to have them pass through interesting sections of woodland. We had the proverbial clay, and it remained for our fingers to model it.

Pickax and shovel, crowbar and spade played their important parts. There was very little need for an ax. Not a single tree was cut down. A few branches were cleared away, but that was all. Rocks that had to be moved were so placed that only their weathered surfaces showed.

In the Spring, with the help of the Park Forester, we transplanted several thousand local flowering plants. Most of these, however, did not survive the unusually long period of heavy rains. There were certain creatures that benefitted greatly by our horticultural efforts. Chipmunks were almost too plentiful in our district. We planted some eight hundred lilies. As far as we could discover, the chipmunks ate the bulbs of every single one. It was a rather costly feeding experiment. We learned something; so did the chipmunks.

The most important problem was that of studying our visitors. We wanted to please them by giving them not only what we wanted The Aim of
the Trail them to have, but what they, themselves, wanted. In the first place we had to bear in mind the fact that these people came to enjoy a day's outing, not to be 'taught' anything. Their idea was to have a good time, ours was to invite them to learn a few things in such a way that they might have a good time in doing it.

It is often more difficult to give something away than it is to sell it. We had nothing to sell and everything to give. Our idea was to make the public realize that the things we had to give were worth taking. The illustrations that accompanied 'Nature's Story' had to be attractive.

At first our efforts at labeling were entirely experimental. Since Bear Mountain is the playground of New York City, our visitors differed in numbers and in types from those for whom Nature Trails had previously been made. Thus, we had no precedent to follow. Although many Boy and Girl Scouts and other camp groups made pilgrimages to our Trails, our principal guests were the young men and women of all nationalities, from the age of eighteen to twenty-five, who came from the city on crowded boats and trains and in unbelievably enormous busses.

To these people, for the greater part, Nature was a closed book. Therefore we attempted to present at least a few pages of that book in such a way that the book itself would be out of sight. We wanted these people to know that: 

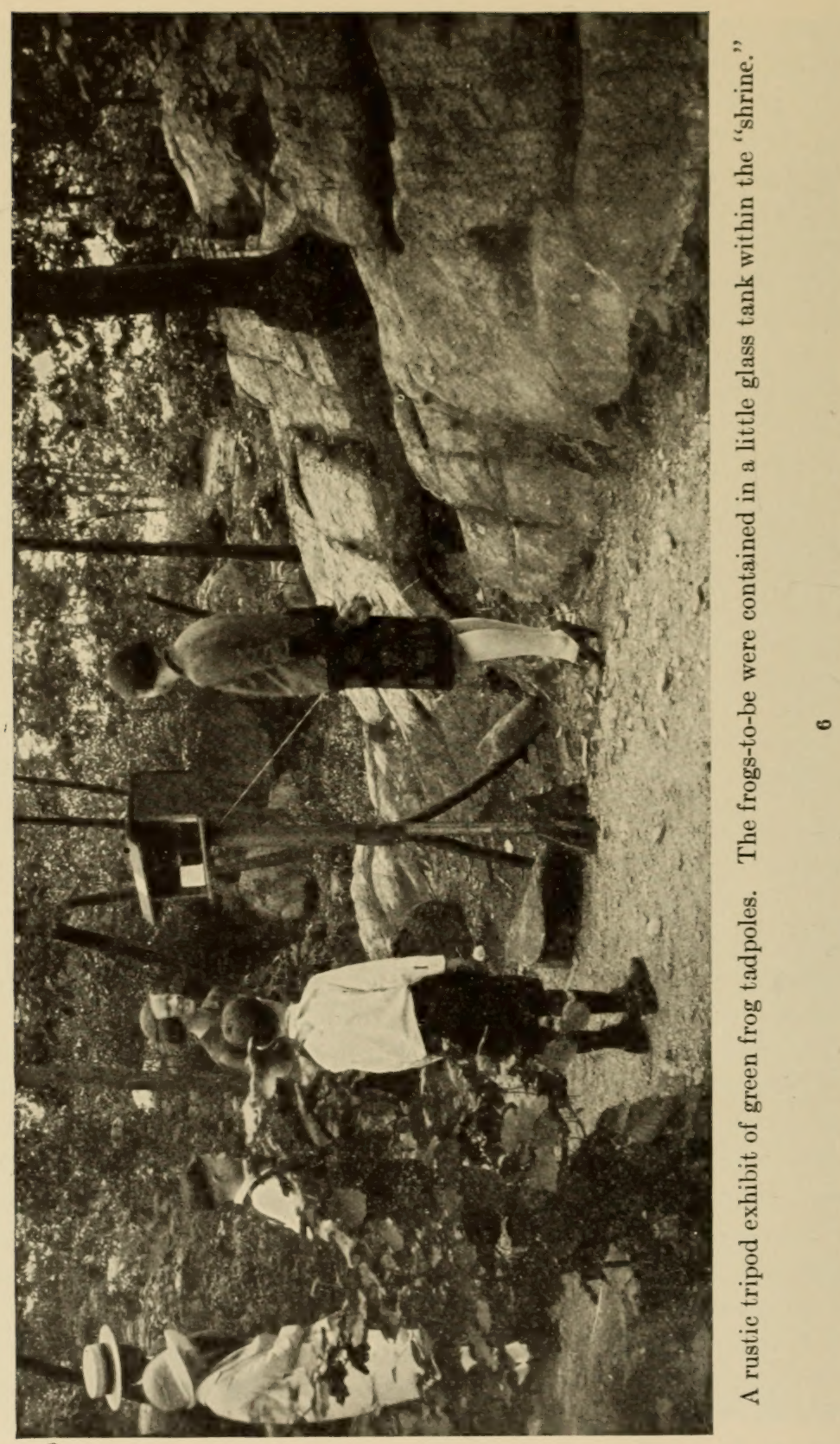


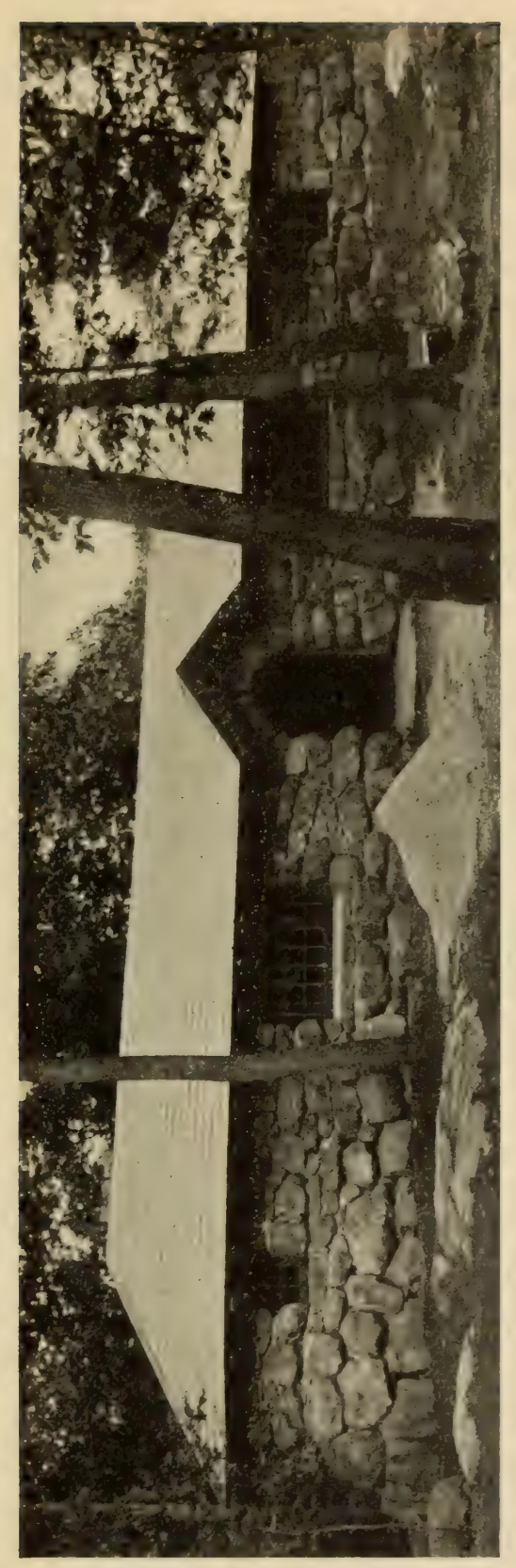

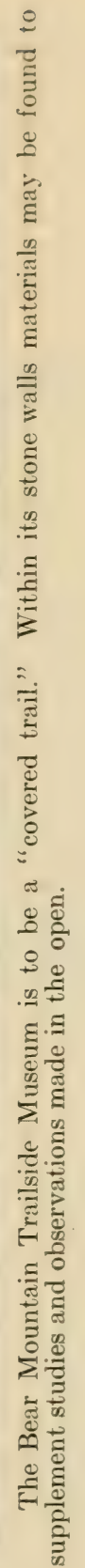


"Nature Study is learning those things in Nature that are best worth knowing, to the end of the doing those things that make life most worth living."

This quotation from that inspiring nature teacher, C. F. Hodge, was

\section{Arrangement of Trails and Museum}

made one of the first signs upon our main Trail. During the first few months one central Trail was labelled. After that, three other paths were laid and a circular return Trail made it possible for the visitor to return from whence he had started. For the purpose of segregating the branches of science we had one Geological Trail, one Botanical Trail, and one Trail that was more or less devoted to Zoology. There was also an Historical Trail.

The main Trail led directly through the small museum building. In this Trailside Museum the only exhibits were those that could not very well be placed in the open. Here cross-reference material could be found to supplement the studies or observations made out-of-doors.

The museuni itself is sixty feet long and fifteen feet wide. It appears to have "grown right out of the ground." No more fitting structure could have been selected to harmonize with the surroundings. Its walls are of rough, glacial boulders that have been found nearby. The stones are covered with mosses and lichens which have been carefully preserved. The building is located in a heavy growth of hardwoods and is practically invisible until one comes upon it. Heavy chestnut doors, with curiously wrought irn snakes for handles, open upon the green-floored interior. The illumination comes not only from attractive electric lamps but from two glass skylights as well.

In one end of the building is a small office and a workshop. Here is a library that may be used by visitors who wish to gain additional information about things that they have seen upon the Trails.

It is a mistake to call this little stone house a museum. We intend to use it as a place that will be in keeping with the woods that surround it upon every side. It will be a "covered trail" rather than a building where mounted and labeled specimens alone are to be found.

We realized, almost from the first, that in order to be at all successful with the public, our labels had to be attractive, not only in subject Labels and material but in size, shape and general appearance as well. Labeling We did not want the label work to appear professional; neither did we want it to look as though children had labored upon it. In order to create a certain respect on the part of visitors for work accomplished it was necessary to strike a happy medium 
between mere good eraftsmanship and a visible 'feeling' of personal appeal. The signs themselves had to show constant care. If many individual exhibits or labels showed neglect the effect of all the other work was, in a certain sense, lost.

It seems that many people today expect good sidewalks and roads to travel upon and good, really expensive, entertainment to enjoy. It also is apparent that many of them expect certain forms of education to

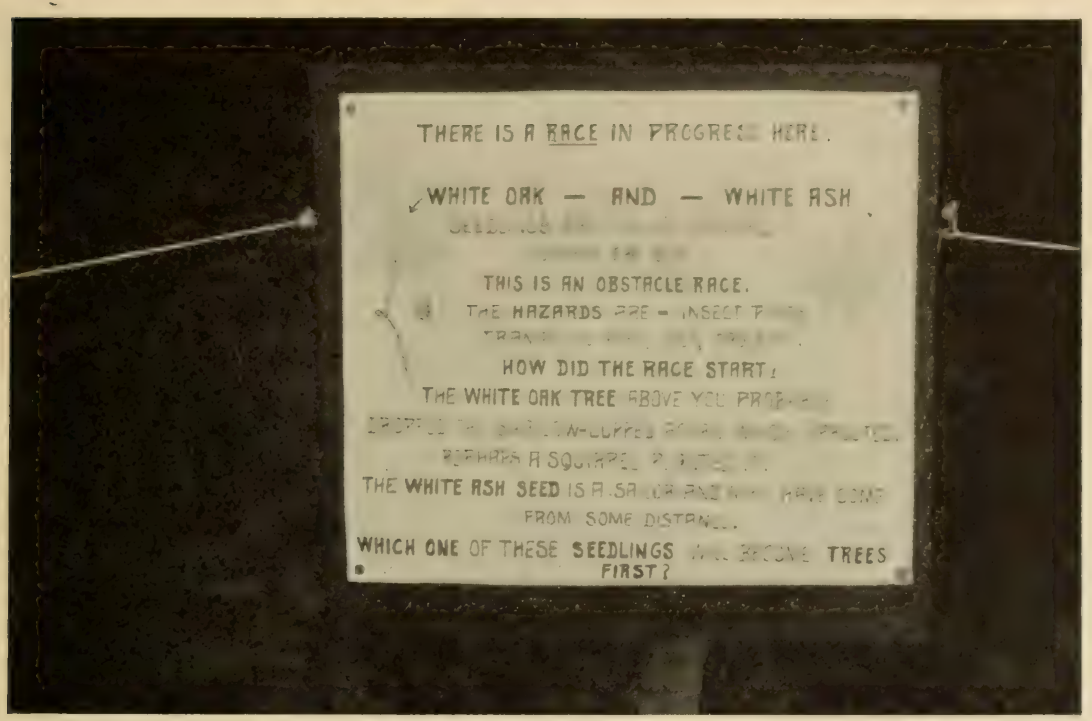

Strings from this label ran to White Oak and White Ash seedlings growing on either side of the tripod. It will be several years before the outcome of this race may be determined.

come to them, if not upon a shining silver platter, at least upon a platter that needs only polish to make it shine. We used neither silver nor polish. However, we did try to make clear the fact that these Trails were not only cared for, but that they were always cared for.

Our first labels had been printed upon linen and heavy paper tags. These soon become soiled and unattractive. They would not do. Then we tried labels placed upon rustic tripods, the tops of which were covered with? celluloid. These were much more durable. Nevertheless, the celluloid soon became discolored. It dried and cracked beneath the sun's heat. This method was also a failure.

After weeks of experimenting with various metals and paints we at 
last discovered a form of label that was much more attractive, in every way, than anything previously used. This new type of sign would resist the weather indefinitely. We used thin sheet zinc, which we cut with large shears, into all sorts of shapes and sizes. After the zine was cut, two coats of white enamel were added, and the lettering was done with ordinary India ink. Two coats of Valspar completed the label. Holes were punched with hammer and nail, and the sign was ready to be hung.

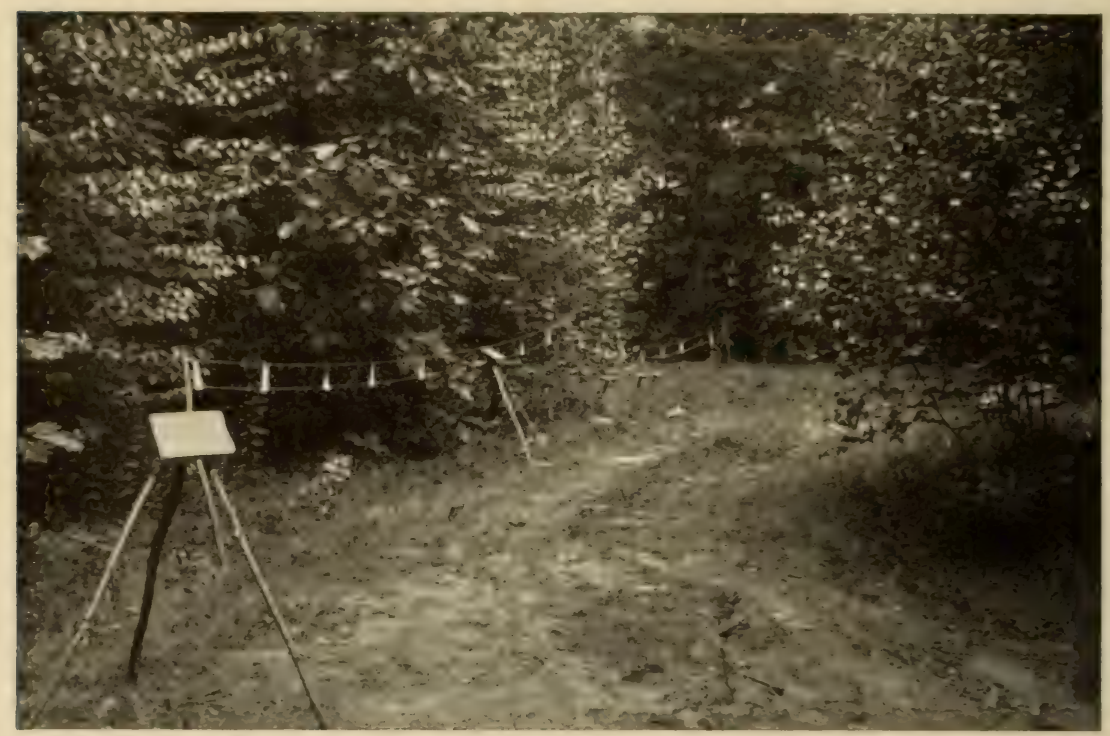

A little "clothesline" of labels to tell a long story and to keep people from walking where we did not want them to walk.

This method required more effort than was necessary for other kinds of labels. However, inasmuch as we designed and placed more than fourteen hundred labels during the season, and plan to add many more, the work was worth while. Soap and water will keep the labels clean for many years.

Labels that were all the same shape, size and color would soon have become monotonous. Thus, very few of our signs were similar in shape or size. Botanical labels were all colored a light shade of green, geology labels were brown, and general labels were white.

A fairly heary grade of aluminum wire was used to secure these labels to trees. The ends of the wire were twisted tightly and then cut 
off with pliers so that they could not be easily loosened by experimenting fingers.

In order to guide the visitor, a large map was placed at the beginning of the Trail. This map gave directions as to what might be seen, and Placing indicated the illustrated objects to be found upon the various of Signs Trails. At the very beginning of the Trail we wanted our guests to know wlat they were approaching. We desired to tell them that someone had labored in their behalf to establish definite things for them to enjoy. Thus, our first sign read:

"This Trail was built for you."

Following the map was a small, rustic stand upon which was the label that endeavored to explain our purpose:

\section{"Signs Along the Trail"}

"How many of us are able to read, unaided, the 'signs' of Nature?-Let the guiding labels take the place of a Naturalist friend who has an interesting story to tell you as you follow the Trail."

From this point, to the museum building, labels were placed at intervals of about twenty feet. It was necessary to have one within sight of the other so that reople would not lose the trail. It was a bit surprising to find how easy it was for these city people to lose themselves in the open.

As visitors entered by one Trail and left by another, signs were so turned that they all faced the walker as he progressed along the path. Whenever it became desirable to tell a story that was too long for one label, several were used. The subject material had to be brief and to the point, without being either formal or strictly scientific. They had to be 'conversational.' We realized, as Burroughs has said, that " Ian can have but one interest in nature, namely, to see himself reflected or interpreted there, and we quickly neglect both poet and philosopher who fail to satisfy, in some measure, this feeling." We tried not to forget that our labels must all be interpretative, that they must tell the story from man's point of view.

At several places where the Trail made a sharp turn we used what might be called the 'clothes-line' idea. We objected, as much as would anyone, to seeing a number of signs strung upon a single horizontal wire. This method had to be followed in several rare instances, in order to keep the public upon the Trails and to protect some especially fine natural object that would otherwise have been trampled. There is a great differ- 


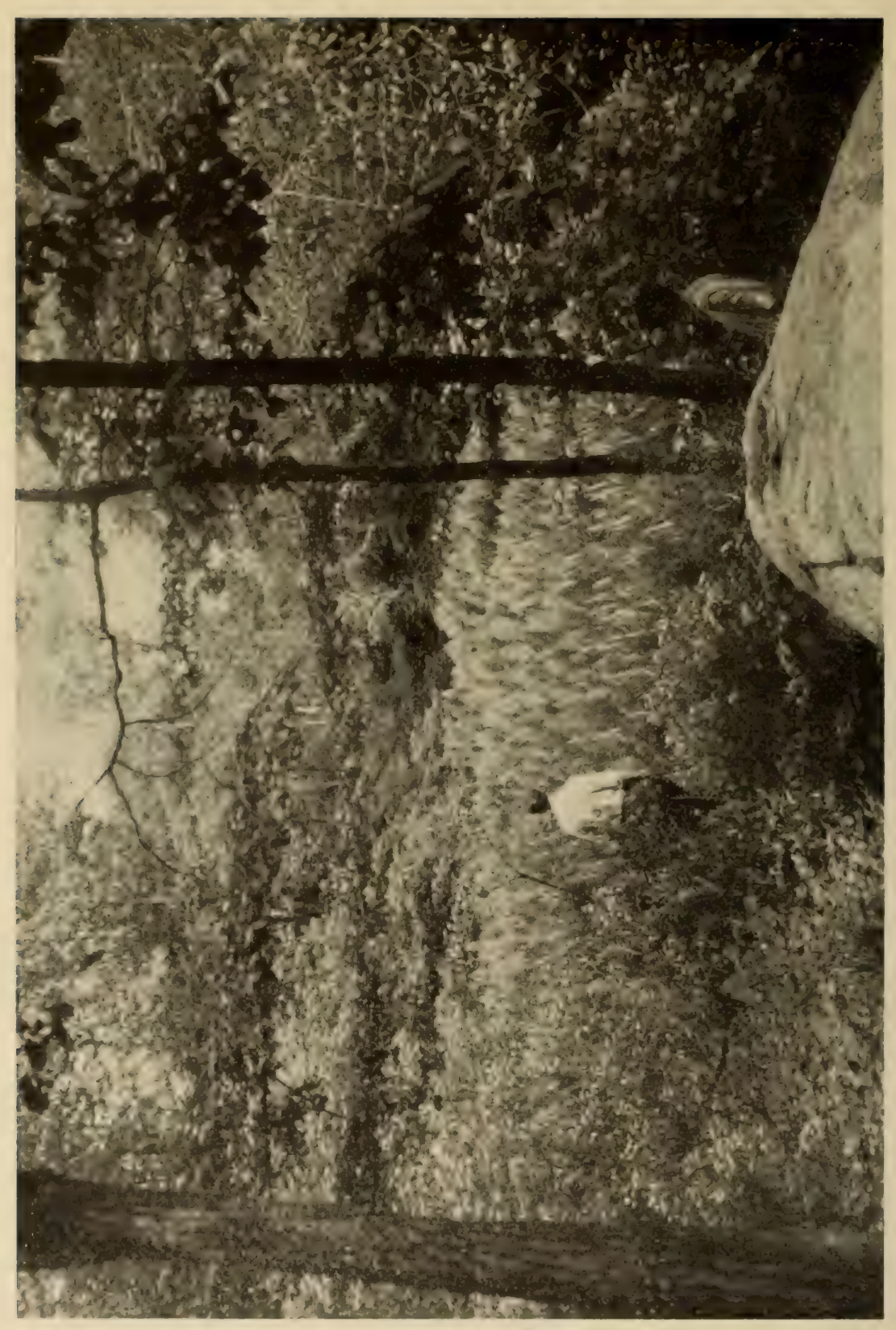

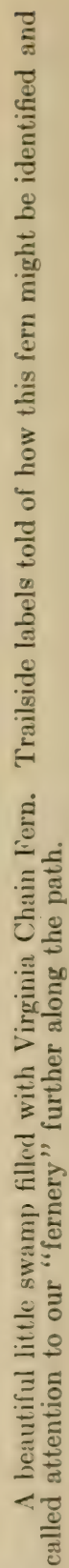


ence between guiding the footsteps of a few people and the freet of hundreds.

A few brief quotations from writings of famous naturalists were given upon labels at points where we felt that an unusually beautiful outlook, either of the woods, the mountains, or the river might hold the guest. As John Burroughs has expressed it in slightly different words, we wanted the public to feel beauty as an experience.

The majority of the first labels upon the Trails were introductory. Botanical, geological, and general signs were interspersed. There

Geology

Trails were many valuable opportunities for geological demonstrations presented by the extremely interesting topography of the Hudson Highlands. Many exposed faces of bed rock

showed surfaces with contorted lines of stratification. Numerous isolated boulders stood as monuments to tremendous changes that had taken place in bygone ages. We told of some of these changes, and introduced our explanations with this sign:

\section{"The Story Beneath Your Feet"}

"This country was very mountainous a long time ago. The Elements,-frost, heat and snow-gradually wore down the high elevations through the ages."

Then with complementary labels we told about the formations of mountains and of various forces that had combined to give the surroundings their present-day appearance.

The Ice Age left its impressions upon this territory in a very definite way. Thus it became possible, not only to tell the story of the rocks, but of the great glacier as well:

"From the North came a great Glacier - a tremendous, moving field of ice-

"The Glacier rounded the hilltops and 'smoothed' the rocks that you see here. It removed huge boulders from the mountains and carried them to other regions. All this was done about 25,000 years ago."

"Evidences of the Glacier's work are all about you."

Labels were placed at various sections along the Trail to tell of unusual geological features. However, it was upon the Geology Trail that the principal attempts were made to present the elementary explanations of the identification of minerals and rocks, and to tell of the ice action upon the local countryside. This branch trail terminated upon a cliff overlooking the Hudson where ice action was particularly 
evident. Here a fine view of the deep, narrow gorge of the river afforded the opportunity of teaching something of geological forces.

Beside the shaded wood-trail, near the cliff-side, we built a stone wall. This was called the "Geology Stone Wall," and was the physical means used to aid in explaining facts about rocks. The specimens to be exhibited were in the form of large rocks placed upon the topmost layer. Suspended labels, with wires leading to the illustrated specimens, told of the origin of the individual rock, its identification and other things of interest. There were some fifty labels in this series.

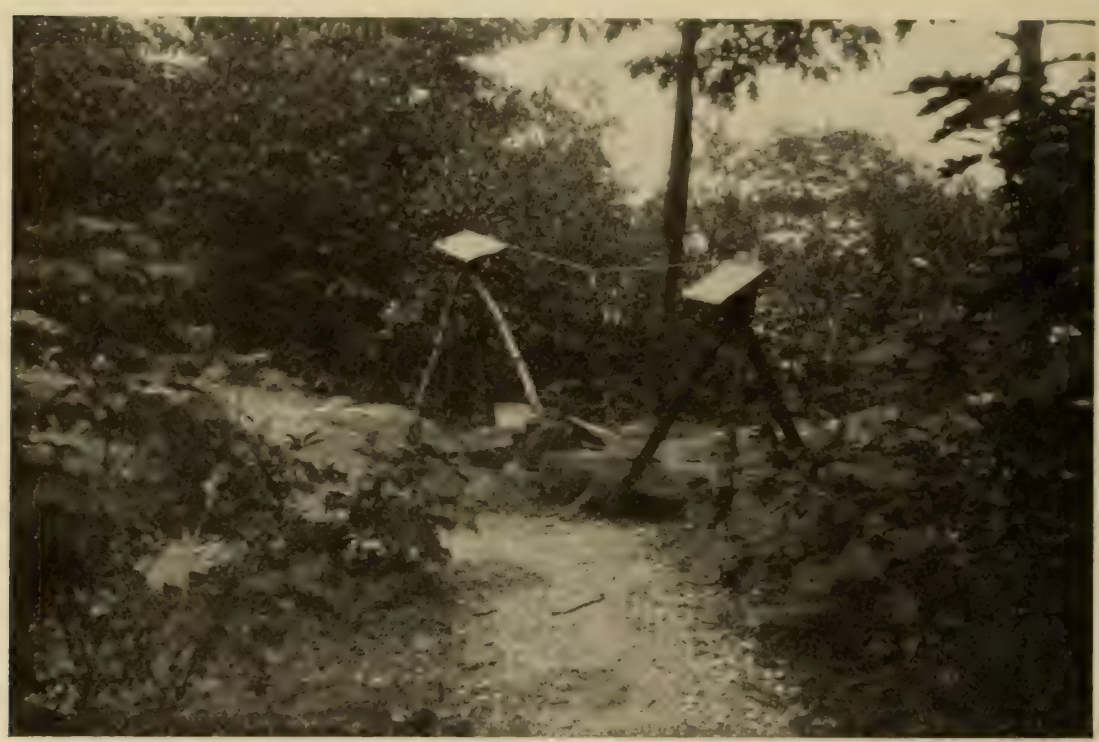

These two labels told "The Story Beneath Your Feet." Needless to say, it was impossible to tell all of the story here. Thus we had the beginning of a continued story that had its climax on Geology Point.

At the end of this "New England" wall there was a table upon which sample specimens were placed. The visitor was invited to take any specimens that he could identify. It became necessary to replace those samples frequently. Of course some of them, at the hands of boys, may have taken unexpected flights into the too convenient river. Nevertheless many people who were interested did collect specimens and carry them away. It might be added that some of these collectors were not always satisfied with the samples upon the tables. They sometimes discovered that there were finer specimens to be broken from the larger, 


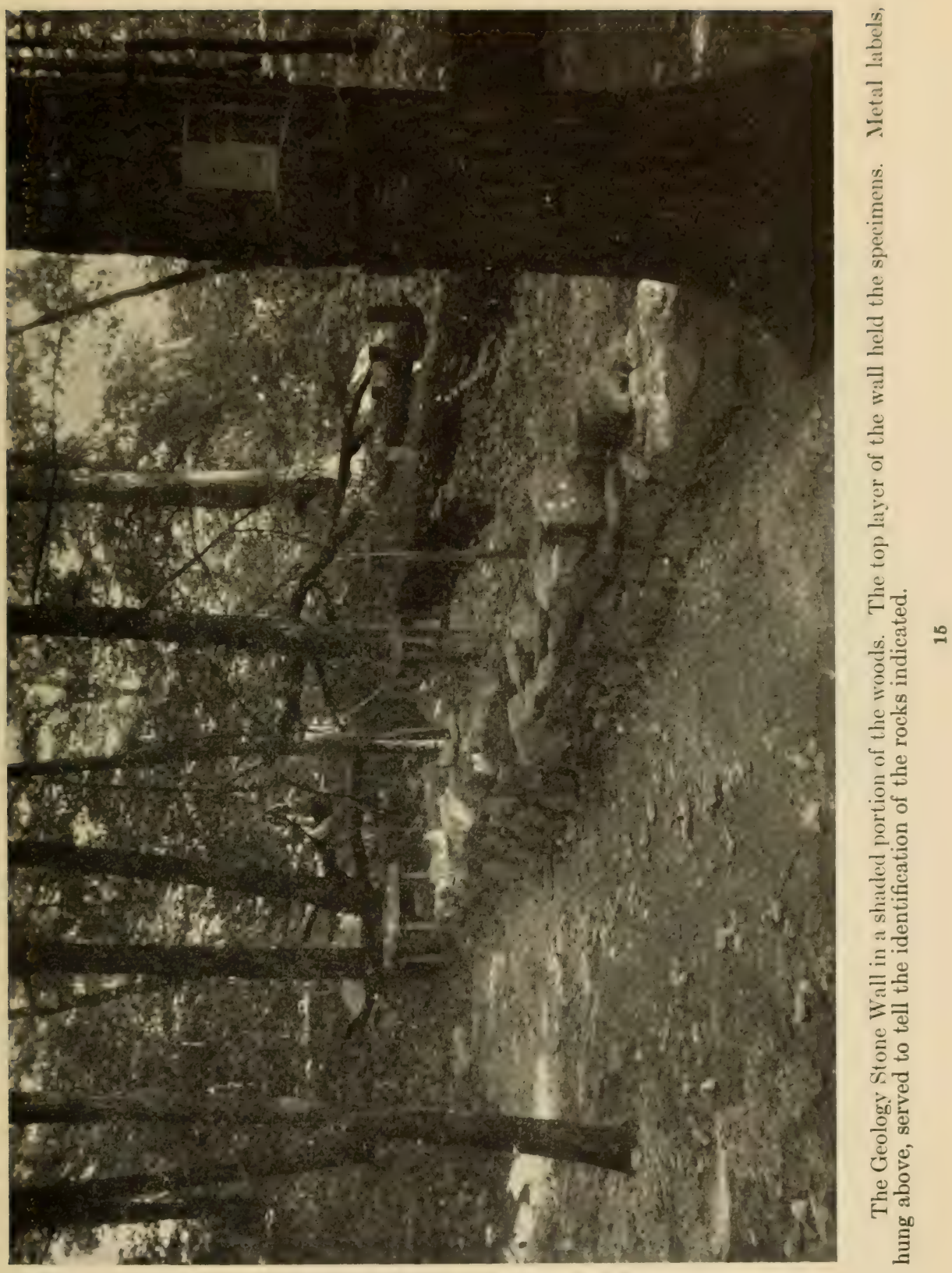


labeled rocks upon the stone wall. At the beginning of the season we had placed a garnet-bearing rock upon the wall. At first this rock weighed about twenty-five pounds. By the end of the season it weighed about five pounds. It lost about a pound a week, due to the ambition of collectors! This weekly reduction did not matter. The world is covered with rocks!

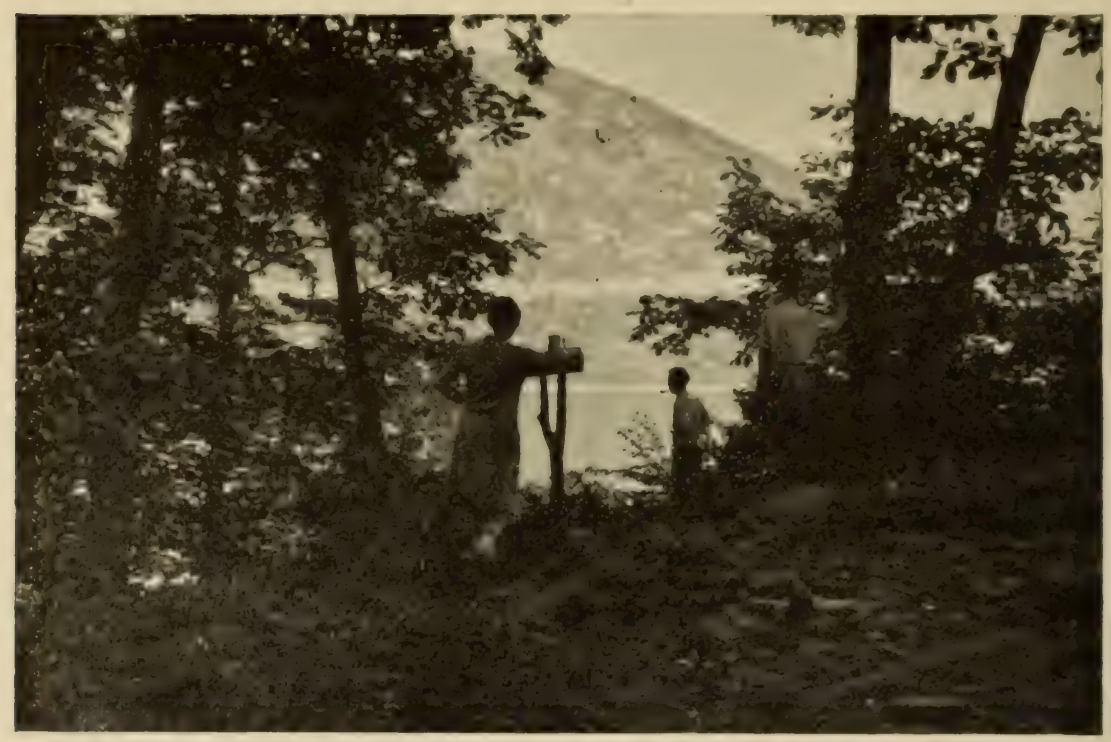

Geology Point commanded a fine view of the Hudson. Here, indeed, there was inspiration as well as information.

Here we taught ideas as well as specific facts. In addition to naming and describing, we wanted to show, as the label indicated, that there were "sermons in stones"; or, in other words, that there was inspiration to be found as well as information.

The out-door teaching of geology, as well as of other sciences, was extended and amplified by the use of charts and models in the museum building. Colored metal diagrams, some of them with movable parts, were mounted in small "shrines" attached to trees and posts on "Geology Point." These diagrams explained such things as landslides, faults and other related subjects.

Usually the most evident things to be observed in the open sections of the East are the trees and other plants. A great part of our time was 
Botanical

Trails spent in learning how we might describe the plants in a manner that would attract our public.

Although we had one Trail especially for Botany, we nevertheless had to place green plant labels in many sections of the main Trail too. In teaching the identification of plants we started with this sign:

"Have you noticed that the leaves of some plants have smooth edges, others have 'saw-teeth,' and still others are differently shaped from either of these? How could this help in telling one plant from another?"

Of course, later on we referred to other methods of identification:

"Your arms are opposite each other.

So are the branches of this White Ash.

What other trees have branches that are opposite each other?"

"The only local Evergreens that bear small cones upon the tips of the twigs are the Hemlocks."

"How many fingers have you? This plant is named

'Cinquefoil' or 'Five Finger.' It has five leaflets."

"The wild Strawberry has three leaflets.

How does it differ from the

Cinquefoil growing nearby?"

To answer the question, "Yes, but what are these plants good for anyway?" we have made many signs like these:

"Indians used the inner bark of the

Basswood tree for string or cord."

"Blueberry Pie is often made from the

Blue-black berries of the

High Bush Blueberry."

"The soft, straight-grained wood of the

Tulip Tree is used a great deal for furniture."

"Socrates drank poison hemlock,-but it was not

from this kind of plant.

Lumbermen make tea from Hemlock tree leaves.

Where are the leaves?"

Beside the Trail stood a boulder that was fairly covered with Rock Tripe. We put these two labels upon the rock, with the result that the "tripe" began to disappear: 
"Rock Tripe is known as Umbilicaria due to the fact that it is held to the rock by a single 'cord' or 'thread" "

and

"Arctic Explorers have used Rock Tripe for food."

It was apparent that the people wanted to see the "cord" or "thread" for themselves. Possibly some imagined themselves Arctic Explorers and tried to eat the plant as well!

Along the sides of the Trail that crossed the brook by means of stepping stones we told something of the biology of plants. We explained that "Leaves are the Lungs and Stomachs" of many plants, and further expanded the subject with additional labels. Overturned trees with exposed roots gave us first-hand opportunity to tell how trees secure and assimilate their food, of what that food consists, and from whence it comes.

If we had taken full advantage of every possibility to point out interesting facts about plants our Trails would have been saturated with Zoology on botanical labels and practically nothing else. We had to the Trails remember that all people are not equally interested in plants. Unfortunately the birds do not explain themselves as well as do the trees and rocks. At various points along the Trails small tripods and tree signs held pictures of birds that frequented that spot. The Catbird's nest was right behind his picture:

"This is a Catbird whose last year's nest is still here."

and

"If you hear a bird nearby singing "Teacher, Teacher, TEAcher, TEACHER!"

it will be the Ovenbird."

"Here is the Ovenbird feeding its young."

We manufactured several birds of wood and plaster. But after having placed these poor voiceless creatures upon branches near the Trail we soon thought differently than when the idea had first come to us. We took the "birds" down. It seemed almost a desecration to put man-made creations upon swaying branches that were meant for the nervous feet of living birds.

Bird houses, feeding tables and baths not only attract the birds but they also inform the public that someone is caring for the flying birds that have been described upon labels.

Early in the Spring we had been presented with a Great Horned Owl that had a broken wing. The boys, for some unknown reason, promptly 


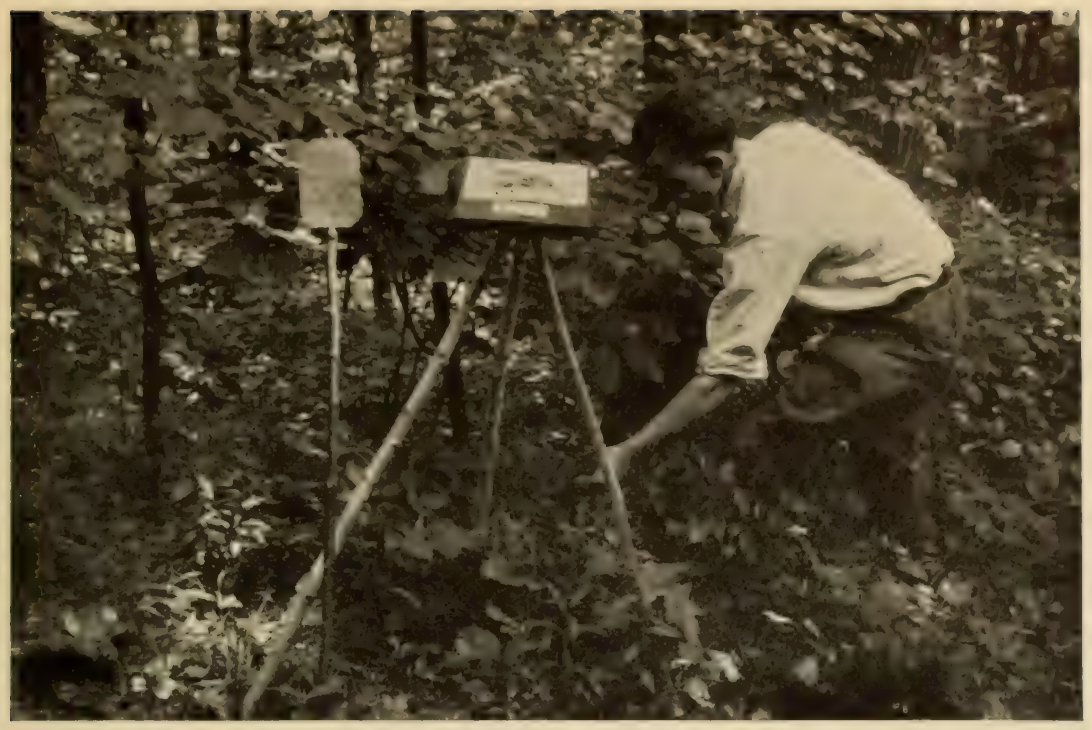

The Oven Bird's portrait was placed upon this tripod. The nearby sign told of the presence of this springtime singer.

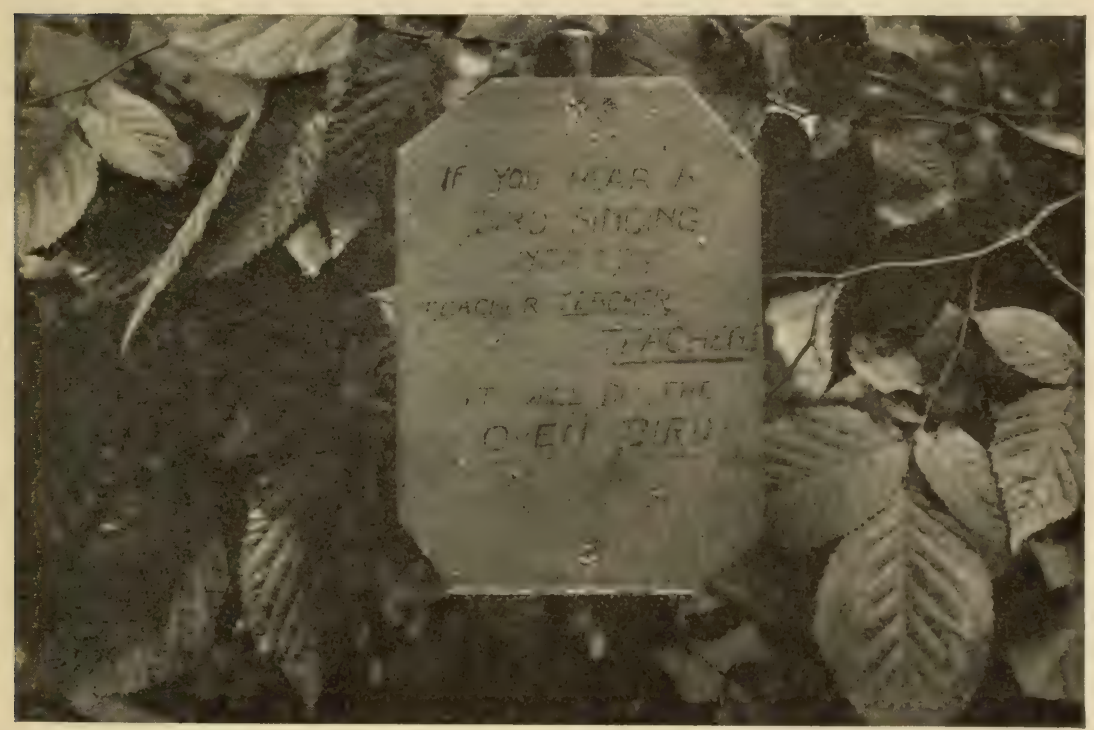

This was the first metal sign upon our trails. 
named this beautiful bird "Josephine." The owl was given a room to herself that she might enjoy peace and quiet until her out-door cage was completed. All that she had to do to make her room really private was to get inside. Probably no fiercer bird ever occupied an apartment.

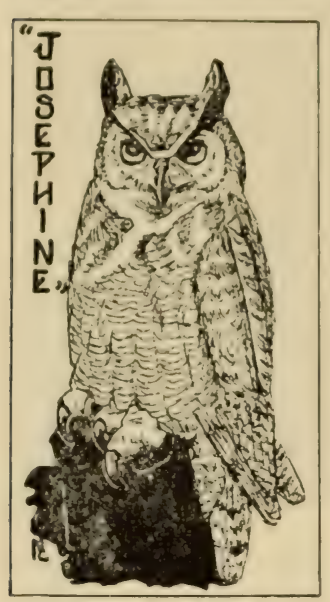
Josephine would fly straight at the head of anyone who attempted to intrude. After her second attack she had no intruders.

When the outdoor cage had been completed, Josephine was transferred with much difficulty to her new horne. Almost at once she became the most attractive exhibit upon the Trail. Children and their parents, young people and old, could never pass the cage without looking for a time into those large yellow eyes.

The most prominent sign near the owl's cage read, "Owls do see in the daytime." Many visitors did not believe this and as a result they walked around and around the cage to find whether or not the owl's eyes would follow them. The eyes never failed. It is a wonder that Josephine did not twist off her head, so often did she turn it around.

This live bird, as we said, was a great "drawing card." Thus we took advantage of the fact and placed labels and exhibits nearby that would interest the public to whom the owl had appealed. We told that: "This owl has a broken wing"--and "When the bird is well she will be released." Furthermore, at the end of the season she was released! What happened to her after that is still another story.

William H. Hudson has said, "We remember what we are interested in." No doubt many people will remember our Trail principally because they will not forget Josephine. Another thing is also quite certain, namely, that people interested by the owl wure much more apt to notice other exhibits than they had been before. Interest begets interest.

The public is interested in things that move and are alive. A grasshopper, properly exhibited and cared for, would attract the average

Turtles and Snakes Frogs and Toads Trail visitor much more quickly than would many inanimate labels. We desired to show some toads, frogs, turtles and snakes. Af it was not quite possible to train these animals to show themselves to visitors, we constructed some cages wherein these small creatures might be kept, 
well fect and content. Our main reason for kereping the few harmless snakes was to enable us to tell various "Facts and Fictions" about them. The living specimens helped to make our explanations much more "alive." Here are some of our labels:

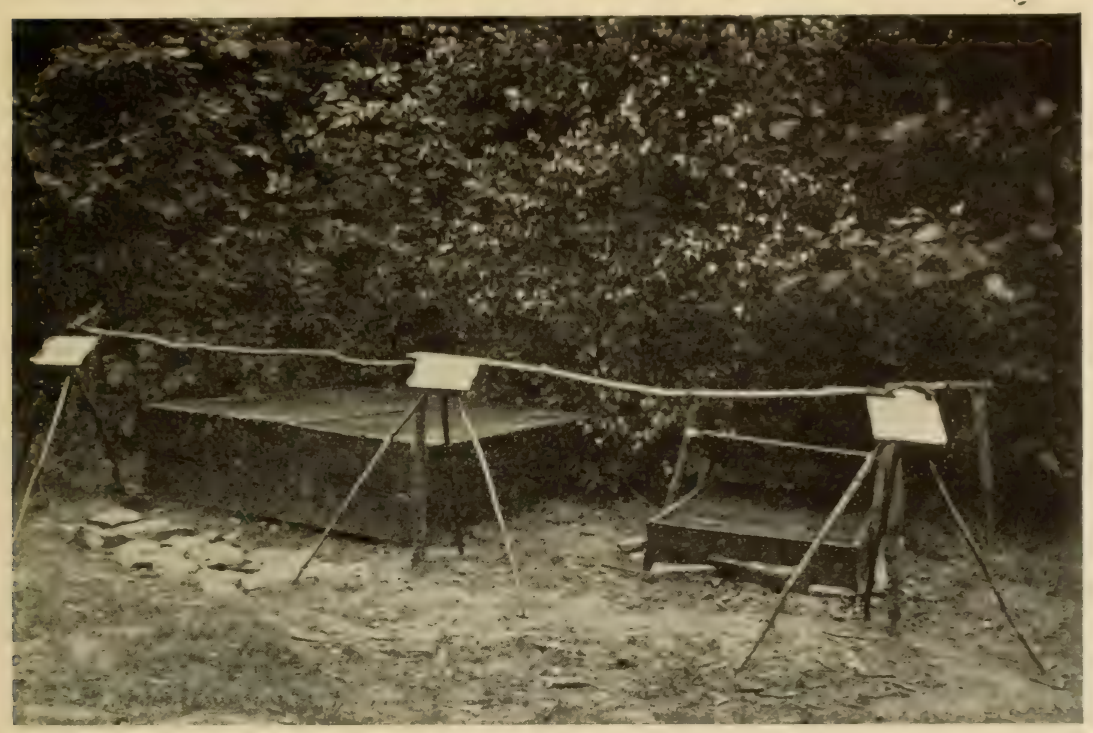

Two turtle pens with their accompanying labels. It surprised us to learn how few people had ever touched a living turtle. Here turtles could be handled as well as looked at.

\section{"Some Facts and Fictions about Snakes The Facts}

It is true that some snakes 'play dead' as a means of protection; the Hog-nosed Snake is our typical example.

It is true that, as a rule, snakes cannot strike more than twothirds of their own length.

\section{Fictions Exploded}

It is not true that snakes are able to charm birds and people.

It is not true that there is such a snake as the Hoop Snake, which takes its tail in its mouth and rolls like a hoop.

It is not true that snakes are slimy."

Exhibits that could be handled were much more interesting to our visitors than were immovable signs and specimens. For this reason 
The Urge an effort was made to place the labels in such a manner that to Touch they could be handled as they were react. Near our ant hill exhibit we had a series of three labels placed in rotation upon a turning triangular platform that had to be manipulated before

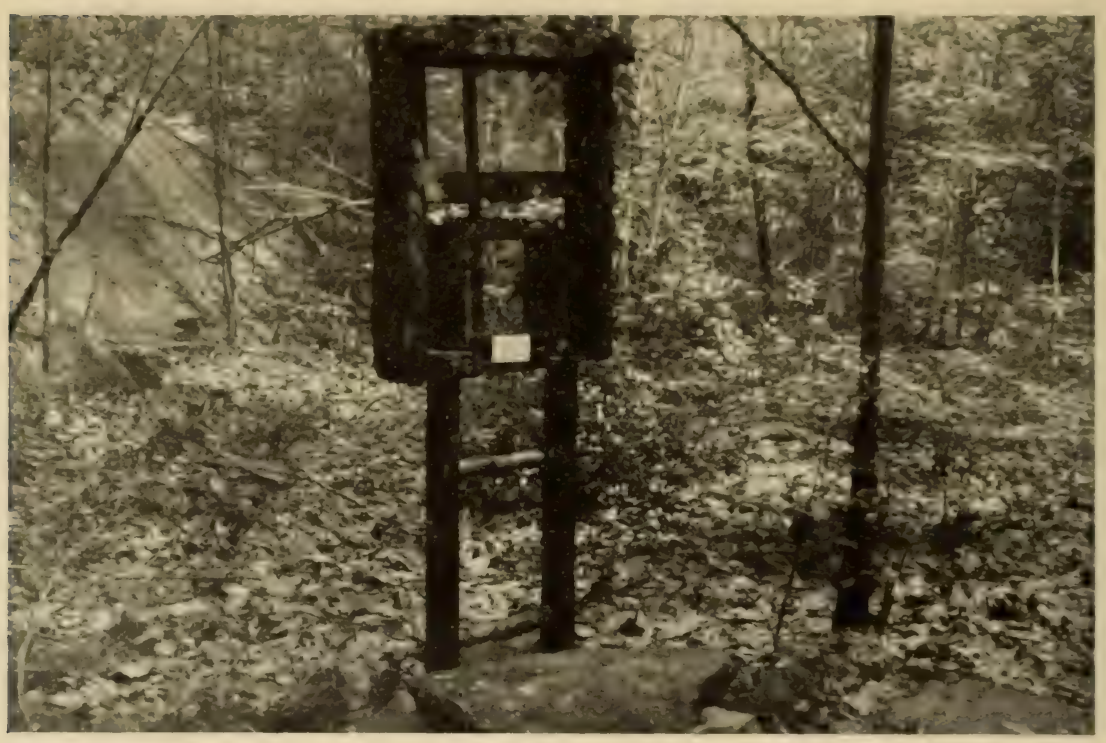

This "shrine" was the home for transients. The transients were Toads that were released after four or five days' residence.

the entire explanation could be read. The first sign always swung back into position after the triangle had been turned. These were the signs:

"The Mound Builders"

1. "An Ant Queen started this hill about ten years ago." (turn)

2. "Since then the industrious workers have toiled to build this home." (turn again)

3. "The Sun supplies the heat. The building materials, as you will notice, are earth, sticks and pebbles. Be careful not to disturb this living ant colony."

In teaching children and adults about the habits of animals we had long known that before our pupils were thoroughly satisfied with the examination of mounted specimens they had actually to touch them. We once had a handsome mounted beaver. In lecturing with this 
animal we spoke of its sharp teeth, its flat tail, and its thick fur. At the conclusion of each lecture the pupils were invited to handle the beaver. It was then that the questions came in full force, not before.

When we wrote labels that mentioned certain physical characteristics of various objects we invariably found that the illustrated objects were handled. This was exactly what we wanted, for we know that unless the people had been interested they would never have touched the specimen.

When people are interested they are active, when not they are passive. Active persons did not fail to use their hands as well as their eyes to gain information whenever the opportunity was given.

The vandalism upon the Trails, as compared with the good work accomplished with the large crowds, was negligible. The more exhibits Vandalism placed, the less was the destruction. It was only necessary to demonstrate to the people that a definite work was in progress, then objects were not disturbed. There were certain times when various labels had to be replaced, but when it is realized that many thousands of people passed over the Trails it is truly remarkable that there was so little objectionable behavior. This incidental vandalism was, at times, a bit discouraging, but, after all, it was part of the day's work to keep the Trails as we wanted them. It was our duty to find methods of preventing vandalism.

At no place did our labels read "Do not!" We always said, "Please," or clse reasoned that to pick flowers or to move exhibits was the wrong thing to do. We had but few "disciplinary tags." Here are several samples:

"Richard Jeffries said,

'A fresh footpath,

A fresh flower,

A fresh delight.'

Please help us to keep this trail fresh and clean."

"Please remember to lake nothing and leave nothing."

"Remember that others will enjoy seeing this Mountain Laurel."

"This is one of the trees from which the bark used to be peeled before people learned that it was the wrong thing to do."

It may have been just possible that there were some people who had not yet "learned that it was the wrong thing to do." Nevertheless this was one method of telling them not to peel the bark from "peelable" trees 
Our greatest curse was the Sunday newspapers. We were grateful to them for giving us considerable publicity, but we wished that the Newspapers week-end editions had fewer pages. Our guests, who usually brought their lunches, were invariably possessed of one or more Sunday supplements. When these people left the Trail: they had the bad habit of leaving their papers behind. Thus the ground in some places was nearly covered with sheets that were scattered in every direction by the wind. Thanks to the park "Pick-up Squad," we were always able to get rid of these papers during the Monday that followed each Friday, Saturday, and Sunday.

Our signs did not do much good as a preventative to paper scattering. However, rubbish cans placed at various intervals did aid to some extent. We did not like the appearance of rubbish cans upon the Trail. Perhaps another season we shall find some solution to the problem. It probably will resolve itself into a matter of further education along the lines of "Live and let live." It remains with us to make the Trail so attractive that people will want to help in keeping it always clean and unlittered.

As the chipmunks prospered by the planting of lily bulbs, so did they enjoy food left by untidy visitors. It was quite a familiar sight on a Monday morning to see these small animals scamper across the Trail holding an olive, a bread crust, or a delectable cracker in their mouths. The cheek-pouches of the chipmunk need never be empty in Bear Mountain, at least during the summer time.

One of the best ways to learn what our visitors desired to find and to know was to walk upon side Trails and upon the main Trail itself, in

Listening and Learning order to listen to conversation. For instance, one man was heard to ask another, "What is that little brown rat with the black stripes down his back?" Of course he meant the chipmunk. As a result of having overheard that bit of talk, there soon appeared upon the Trail a colored picture of the chipmunk, with several labels telling of his habits.

Yes, the best critics were our visitors. They were honest in their opinions and straighforward in their comments. We knew that the success or failure of our project lay in their hands. Thus we always welcomed suggestions.

As our Trail area included lands that had played an important part in the Revolutionary War, we could not but tell something of the history 
The

Historical

Trail

of the region. Thus we had an Historical Trail with about two hundred labels marked with red, white, and blue. This Trail extended to a promontory overlooking the Hudson not far from where one of the chains had been stretched

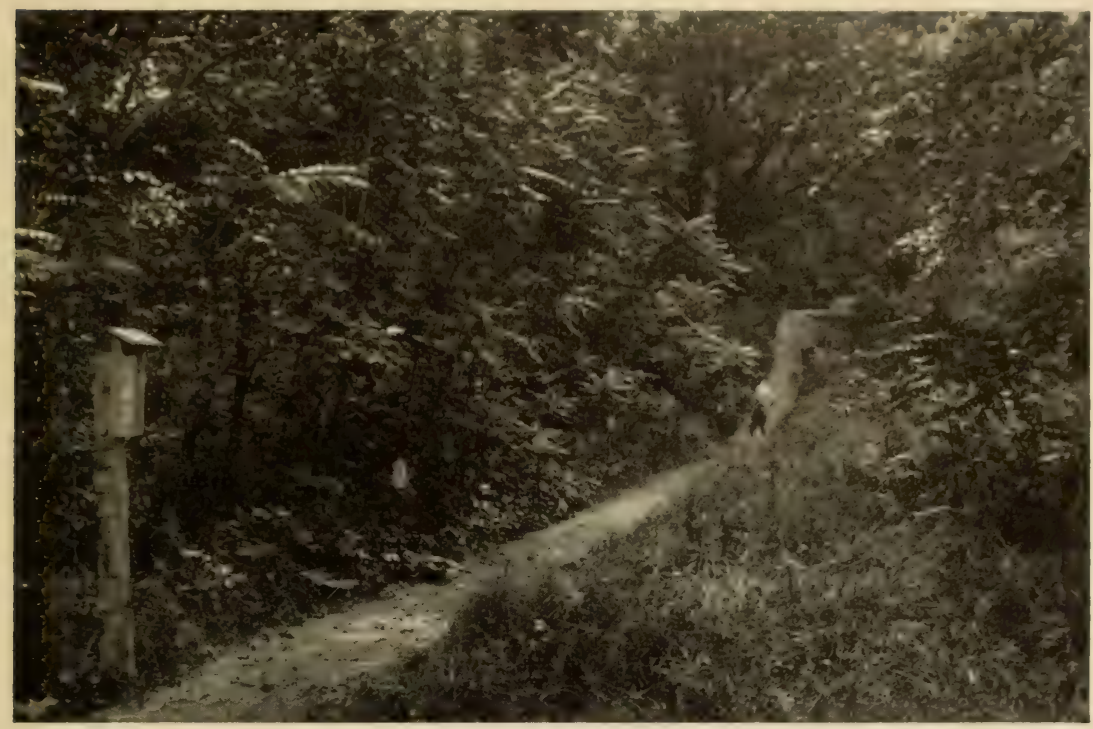

Historical trail on the site of old Fort Clinton. Here the story of local Revolutionary engagements was told.

across the river by the Colonial forces to halt the British in their movement northward.

Along this path, in chronological order, the labels told the historical story of the navigation of the Hudson from New York to Albany by Henry Hudson, the Dutch settlements on Manhattan Island, and the extension of Dutch forts, trading posts, and communities beyond the Highlands to Newburgh, Kingston, Poughkeepsie, and Albany.

The course of historical events was thus brought up to the beginning of the American Revolution, with labels and maps to explain the military happenings of 1776 and $\mathbf{1 7 7 7}$. The telling of the story of local engagements was all the more vivid because, as our visitors read, they realized that they were standing upon the ramparts where Americans, British, Highlanders and Tory troops fought and died in savage encounter not so long ago. 
The labels upon this Trail were not all strictly historical. One of them read:

"Henry Hudson saw these hillsides covered with evergreen trees. Where are they now?"

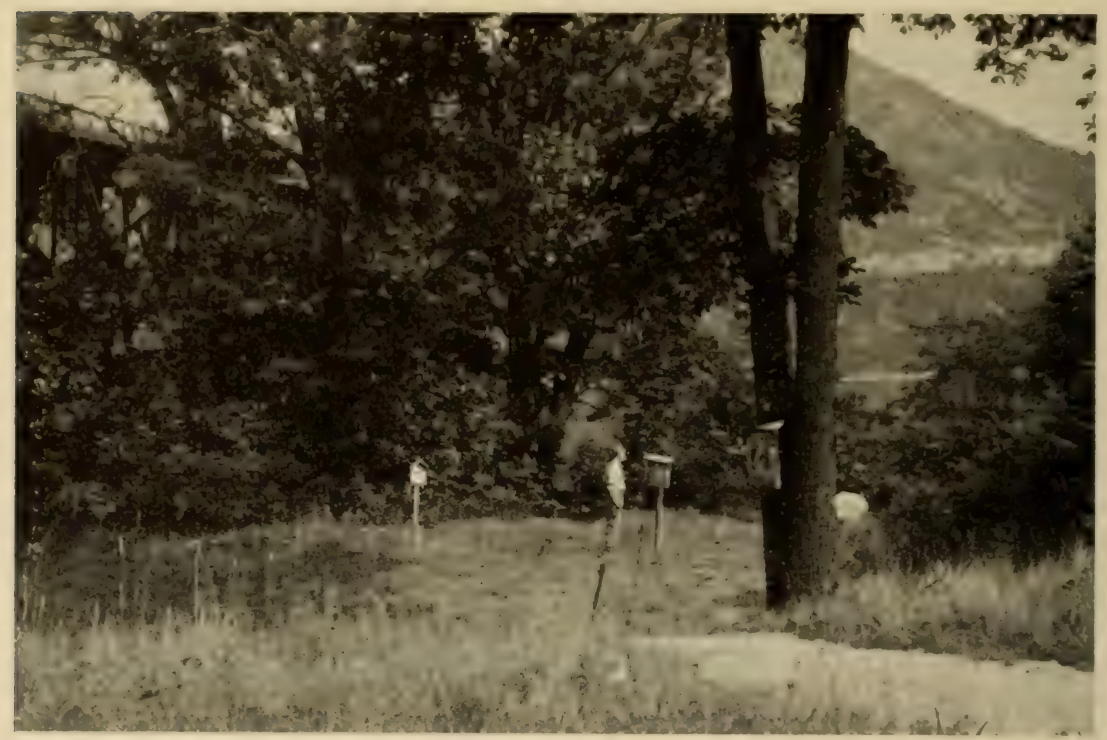

Out-door maps of metal were used upon Historical Point. Bear Mountain Bridge may be seen in the photograph with Anthony's Nose across the river.

Classes from schools in nearby towns visited our Historical Trails so that they might leave their books at home and study history where history was made.

There seems to be almost no limit to the objectives and the educational possibilities of these outdoor Trails. They are certainly powerful Conclusion aids to the teaching of conservation. They instil respect and admiration for Nature, and they help to convince the traveling, shifting public that there is something worth stopping to look at in the woods, fields, and streams.

The greatest handicap that we found in our work was that the week had too few days and the days not enough hours. The building of a Nature Trail is happily a project that can never be finished. There are ever new methods to be discovered and new contacts to be made with interested people. 


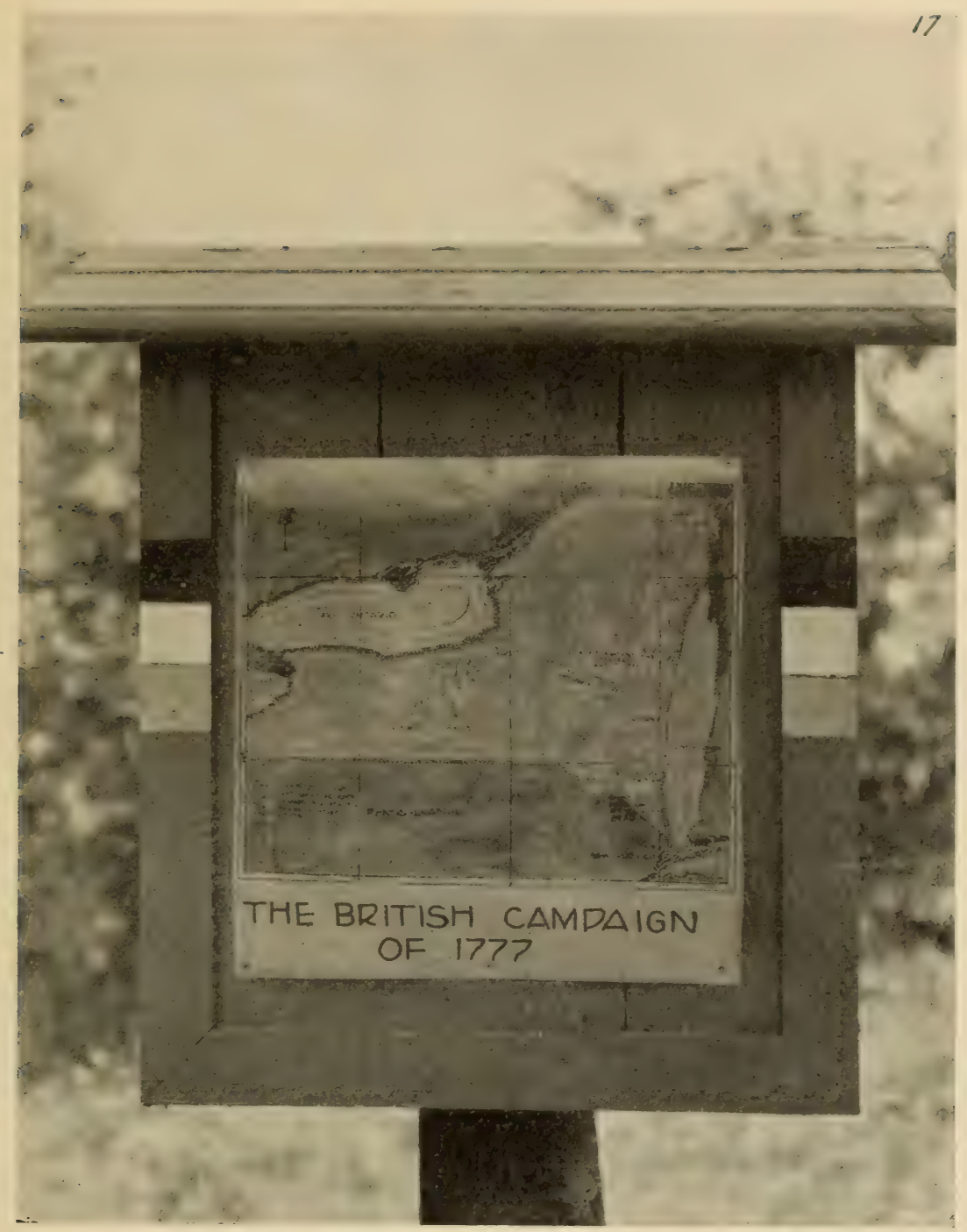

A map painted upon thin sheet zinc. 
The balance between teaching and learning was so delicate that it would be difficult to tell which of the two weighed the most upon the scale of a fascinating experience.

A labeled flower growing beside the trail is far better than a pressed specimen in a notebook. A rock is much more natural in the soil than behind glass. People visit parks and journey away from cities to be in the open. Let it be in the open that they receive their instruction and develop their interest in Nature. Nature Trails teach appreciation for things that cost nothing, yet can never be bought. Among our hills, far from the noise of cities, there was peace. If, in our efforts to give knowledge, we also gave a bit of that same peace and contentment, then our labors were not in vain.

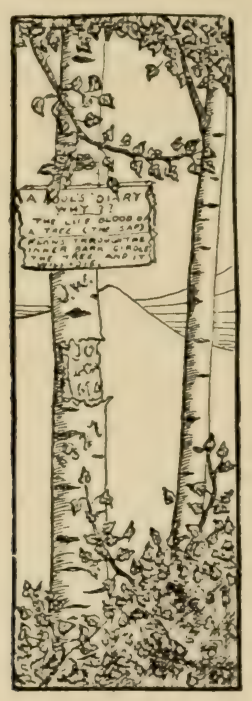




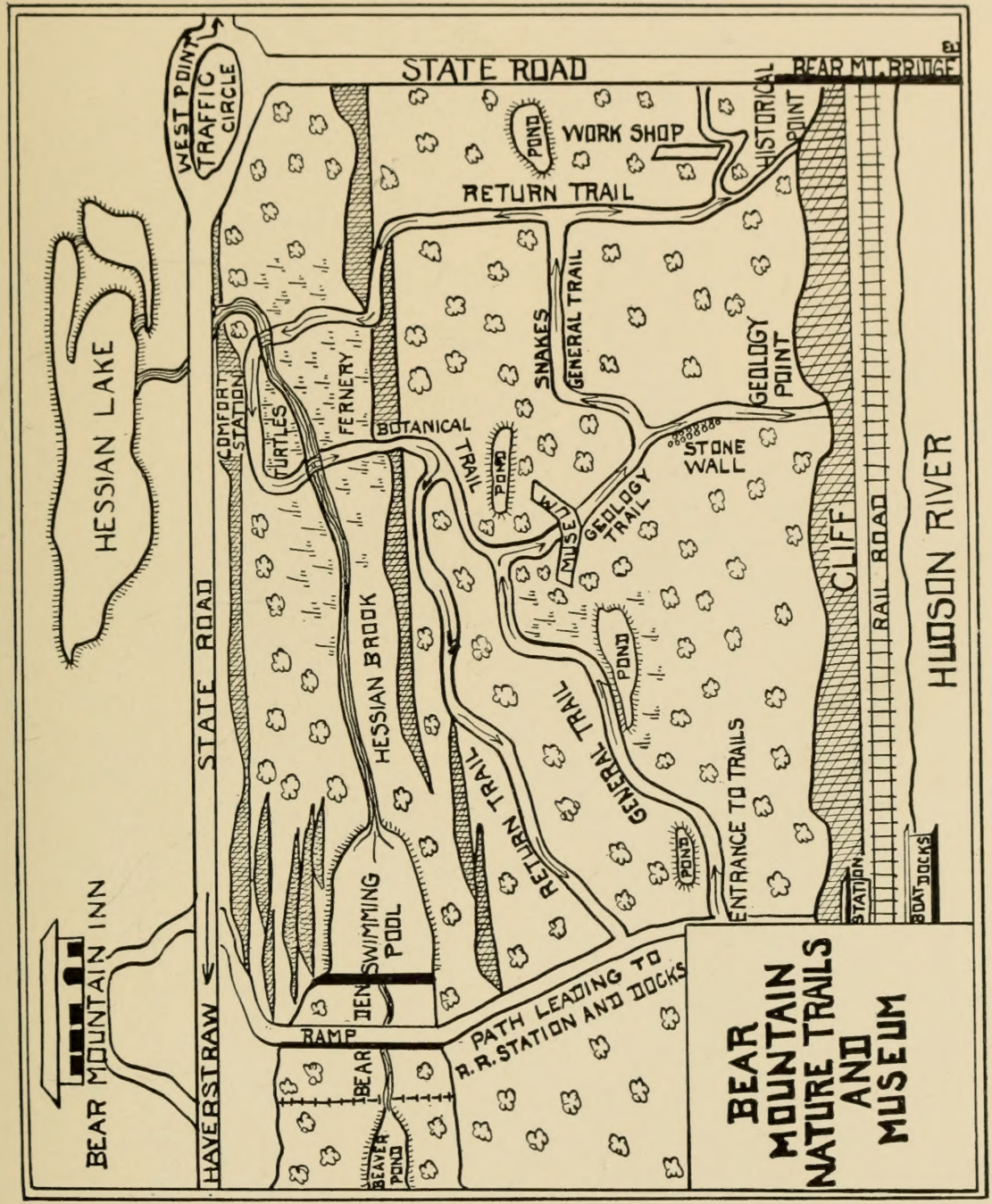



3
3
3 


$$
100191874
$$

